\title{
DESCRIPTION OF TWO NEW SPECIES OF THE GENUS CRYPTOGNATHUS (ACARI : CRYPTOGNATHIDAE) FROM EGYPT
}

FAWZY, M. M. H. , A. M. KHALIL AND E.M.A. YASSIN

Plant Protection Research Institute, ARC, Dokki, Giza, Egypt

(Manuscript received 8 November 2010 )

\begin{abstract}
Two new species of the genus Cryptognathus are described from Egypt; Cryptognathus (Favognathus) rosetta n. sp. on debris of cantaloupe at Rashid City , Beheira Governorate and Cryptognathus (Favognathus) aegyptiaca n.sp. under maize at Damietta City, Damietta Governorate. Adult female and male were described and illustrated.
\end{abstract}

\section{INTRODUCTIO N}

Cryptognathids are very small mites which are collected infrequently and in a small numbers from soil, leaf litter, mosses, lichens and under stones. They appear to be cosmopolitan in distribution, but very low is known of their habits. It has been suggested that they are predatory animals (Baker and Wharton, 1952; Meyer and Ryke, 1959), but their mouthparts are so delicate, with elongate, edentate chelicerae , so that they may be selective feeders on fungal spores. The needle-like chelicerae may also therefore, be adapted to select algal cells or else and this seems the best of several alternatives to pierce plant cells and drain the contents (Luxton, 1973).

The genus Cryptognathus was established by Karmer in 1879, with Cryptognathus lagena as the type species .

In 1893, Oudemans placed the genus in the Raphignathidae, with which family it has close affinities (Summers and Chaudhri, 1965) .

However, the structure of the gnathosoma and of the integument of Cryptognathus are so distinctive that in 1902 Oudemams made it the type of genus of new family, the Cryptognathidae. The family still contains but one genus .

The second species of the genus was not described until 1916 when Berlese established Cryptognathus cucurbita as well as a new subspecies Cryptognathus cucurbita subsequent records of the family and genus mainly identified newly found specimens with those of the either Kramer or Berlese (eg. Thor , 1931 , Womersely , 1935 , Baker and Wharton, 1952).

However, in 1926, Hirst confidently erected a new species Cryptognathus australiensis. Thirty-two years were to elapse before a further new species (Cryptognathus sternalis Krantz 1958) was described from Oregon, and in the following year Meyer and Ryke published a second subspecies to Berlese's Cryptognathus cucurbita. The mites species Cryptognathus ochraceus of Summers and Chaudhri was recorded from Israel by Gerson (1958). 
Then in 1965, Summers and Chaudhri published ten species mainly from California to those already known, but also established detailed basis for further taxonomic work for Cryptognathus because the description of Kramer and Berlese is inadequate.

In 1968, a further species (Cryptognathus barrasi) was established from Lousiana by Smiley and Moser .

Summers and Chaudhri (1965) discovered that the eleven species of family Cryptognathidae could be readily divided into two distinct groups on the basis of the number of morphological characters .

This species group is called the "Favus" group which has two pairs of paragenital setae and the presence of a wedge - shape simpled prosternal apron while the second group is called "imbricatus" group which have three pairs of paragential setae and the prosternal apron is cresent-shaped and smooth .

\section{General Morphology of the Genus Cryptognathus Kramer 1879}

The mites are flattened dorso-ventrally, encased in a rigid integument which is sculpted to a greater or lesser degree. One of the most interesting features of these mites is the unvarying presence of a "hood", which is a sclerotized projection anterodorsally forming a ventrally in complete collar around the mouthparts .

The shape of the body is abroad or narrow oval, the mouthparts consist of a pair of five segmented palps, with the chelicerae often fastened same way posterior to the bases of these. the chelicerae are edentate stylets, and mostly elongate .

The mouthparts are flexibly attached to the idiosoma bears two pairs of eyes and eleven pairs of smooth dorsal setae . ventrally there are six pairs of idiosomal setae. The anal aperture of the female is terminal, whereas that of male is postereodorsal .

There are either two or three pairs of paragenital setae present. Ventrally at the base of the hood there is a sclerotized plate, prosternal apron which may be either wedge-shaped and dimpled in favus-group, or crescentic and smooth in imbricatus group.

The coxae of legs are juxtaposed and fused into ventral plate the pretarsi have two simple claws and empodium .

A part from the positioning of the anus males be distinguished from the females by their three pairs of postero-dorsal setae ( $c, d$ and le) standing together as a cluster. Morever, the male genital aperture appears to be terminal, and the solenidia of tarsi I - IV are twice as large as the corresponding solenidia of the female. 


\section{MATERIALS AND METHODS}

Samples of debris under Cantalop from Rashid City, Beheira Governorate and under maize at Damietta City, Damietta Governorate were collected. In laboratory, the samples were investigated by stereomicroscope and different mite stages were separated by camel hair brush. collected adult and different stages were cleared by Nesbitt's fluid, mounted in Hoyer's medium on glass slides and examined microscopically .

Mites were identified according to Luxton, 1973 and kept in the collection of Plant Protection Research Institute. The two new species of genus Cryptognathus were described and all measurements are in microns.

\section{Cryptognathidae Oudemans 1902 . Cryptognathus Kramer 1879 Cryptognathus (Favognthus) rosetta, sp.n.}

Female :Length of idiosoma (including hood and anal covers) $268 \mu$ and the width

$161 \mu$ at the level of setae la. Gnathosoma not protruded on any of specimens .

Collar : Rime of collar truncated smooth, dimples round or oval, dimples very clear, roughly circular larger on lateral edges of hood, 6 of 7 dimples in each longitudinal row - length of hood $40 \mu$ and width $80 \mu$.

Gnathosoma protrusible , apearant full extension projects palpgenu to level of foreleg claws. Hood smooth anteriorly with 6-7 dimples per longitudinal row

Dorsum : (Fig.1) Oval shape with rough striated four rows of dimples around the edge of dorsal plate and carry many pares arranged on these rows of striation. Parallel to the previous striation there is a pair of striation on each side of idiosoma bit without pores.

The rest of dorsum surrounded by the aforementioned striation covered with punctuation . The setae ae and pv behind the hood long flagellum shape with length $33 \mu$. The setae po , d , le , pr , sc, and la lied on striated pond with length $16.7 \mu$, $22.3 \mu, 30 \mu, 18 \mu, 23 \mu, 37 \mu$.

The state $a, b, c$ lied on punctuate area of dorsum . Dorsum with eleven pairs of smooth dosal setae and two pairs of eyes antero - laterally .

Venterum (Fig.2). With six pairs of smooth setae va,vb,vb,vd,ve and vf. Anal aperture of the female terminal with two pairs of setae while the genital plate associated with two pairs of paragenital setae on each side. A prosternal apron area which may be wedge -shaped or dimpled at the base of the hood ventrally 
Coxae of I , II and III legs juxtaposed and fused into the ventral plate while coxae IV separated the ventrum striation began from coxae IV around the posterior edge of idiosoma, the hole ventrum is punctuated.

Chelicerae: (Fig.3) fused together with basis capituli with length $62.8 \mu$ without capitali dorsal setae , 11 smooth pairs . setae a shorter than distance (a-b) dorsal shield non-reticulated medially, porous, lateral edges show to 7 rows of striations carried punction on it .

Ventral shield : non-reticulated and porous, pores equispaced as in dosal shield on each side, longitudinal striations $\mathrm{m}$ from coxae IV until genital opening which represent by value attached interiorly and associated with two pairs of genital small setae prosternal apron wedge -shaped dimpled with 2-3 dimples in a longitudinal row

Sternocoxal portion with punction legs coxae with pores . length of legs I - IV $164 \mu, 116.4 \mu$, and $134.3 \mu$. length of chelicerae $62.8 \mu$. Length of idiosoma $268 \mu$ and width $16 \mu$, dorsal setae : ae $37.9 \mu$, pv $28.8 \mu$, po $18.40 \mu$. a $10.4 \mu$, b $32.8 \mu$, a-a $60 \mu$, b-b $68.6 \mu$, c-c $47 \mu$, D-D $20.8 \mu$.

Legs: (Fig.4): Setae on legs: trochanters $1,1,1,1$ femora 3,3,1,2, genua 2,3,2,2 tibiae 3,3,3,2 tarsi 9,4,6,6 .

Male : (Figs.5,6,7,8) Dimensions of idiosoma ; length $194 \mu$, width $112 \mu$ sculpturing number of setae in male rather to that of the female .

Material examined: A holotype female and an allotype male were collected from debris under cantaloupe plant in Beheira Governorate. Two paratype females had the same information. All were kept in the collection of Plant Protection Research Institute, Giza, Egypt.

This species is coincided new and strands nearly to Cryptognathus dama but differs in dorsal shield non reticulated medially and punctuated. Lateral edges show longitudinal striations instead of fine developed reticulation as in C. dama. Seven longitudinal striation in $C$. dama while in C.f.rosetta four rows of longitudinal lateral striation carried many dimples and these rows attached transversally while they are separated in C.dama .

\section{Cryptognathus (Favognathus) aegyptiaca sp.n.}

Female : Dorsum (Fig.9) Oval shaped, idiosoma $455 \mu$ long , $119 \mu$ wide, dorsal setae 11 pairs smooth ae $29.4 \mu$, pv $35.3 \mu$, pr $29.4 \mu$, po $29.4 \mu$, cc $44 \mu$, a $50 \mu$, b $53 \mu$, c $55.8 \mu$, d $41.2 \mu$, ca $41.2 \mu$ and le $35.3 \mu$, respectively. Gnathosoma protrusible dorsal shield carry two pairs of eyes .

Hood concave interiorly with dentes ,6-7dimples per longitudinal row with length $37 \mu$ row a shorter than distance a-b 
Dorsal shield non reticulated medially, porous, lateral edges show longitudinal striations, attached interiorly and posteriorly . Dorsal setae smooth long : $29.4 \mu$, pv $35.3 \mu$, pr $29.4 \mu$, po $29.4 \mu$, sc $44 \mu$, a $50 \mu$, b $53 \mu$, c $55.8 \mu$, d 41.2 $\mu$, la $41.2 \mu$ and le $35.3 \mu$.Ventral shield punctuated and porous, pores equispaced asim dorsal shield with longitudinal striations laterally and around the genitalia . These striations carry many dimples prosternal apron wedge -shaped, dimpled with 3-4 dimples in longitudinal row . legs coxae with pores .

Chelicerae (Fig.11) Length $117.6 \mu$ and width $67 \mu$, redipalp $194 \mu$. Venter : (Fig.10). With six pairs of setae (va - vf) respectively from prosternal apron to genital anal and genital covers separated, anus terminated on dorsal shield .

Female genital on ventral shield surrounded by two pairs of paragenital setae for that this species follow the favus group and similar to species Cryptognathus (favus) magnus nut its length $455 \mu$ id longer than c.(f) magnus ; $429 \mu$ while uts width $119 \mu$ less than the width of c.(v) magnus $232 \mu$.

Collar : Rime of collar concave not truncated as in c.(v) magnus with 6- dimples in longitudinal row of hood while 7-8 fimples in c.(v) magnus . The length of dorsal pairs of setae longer than the setae of $c .(v)$ magus .

legs (Fig.12), 4 pairs I - IV measuring $332.3 \mu, 264 \mu$, and $279 \mu$ in length respectively .Coxae of legs are punctuated .

In $\boldsymbol{C}$.(f.) magus there is some striations between punctuation on dorsal shield while in $\boldsymbol{C}$.(f.) aegyptiaca these striation not found and also in ventrum.

\section{Male (Figs.13,14,15,16):}

The two sexes are much alike in general form and are distinguishable primarily by their genitalic organization .

Anal aperture of the male is poster dorsal, higher and dorsal plate than that of the female and the 3 pairs of posterior setae (c, d, le ) lie close together in a compact cluster .

The front rim of the anal opening is located very close behind this group of setae this aperture appears to be terminal in the striated membrane between the two body plates . Males posses a large edgius expanded from setae vc to setae vf ventrally . Males have additional tarsal large solenidion $\mathrm{w} \delta$ on the tarsi of legs .

Habitate : This species found in debris of maize in Damietta Governorate . Type material : 3 क holotype and $2 \hat{\jmath}$ paratype and $7 \delta$ holotype, $3 \hat{\delta}$ paratype found in maize debris in Damietta Governorate. 
Fig1-2 
Fig 3-4 
Fig 5-6 
Fig $7-8$ 
$9-10$ 
11- 12 
13-14 
15-16 


\section{REFERENCES}

1. Baker E. W. and G. W. Wharton. 1952. An Introduction to Acarology . Macmillan, New York . 465 pp.

2. Berlese A. $1882-1893$. Acari Myriopoda et Scorpions hucusque in Italia reporta - palaver.

3. Berlese A. 1917. Centuria Seconda di Acari nouni Redia .,125 - 177.

4. Gerson U. 1968 . Some Raphignathoid Mites from Israel, J.nft.Hist.,2:429 437.

5. Hirst S. 1926. Some New Mites of Suborder Prostigmata . Ann -Mag - Nat Hist .,9(18) : $609-616$.

6. Kramer P. M. 1879 . Meber die Mibebattungen Hodge Raphignathus Dug ; caligonus Koch , Und die neue Gattung Cryptognathus . Arch .f.Nature,g., 45 (1) $: 142$

7. Luxton M. 1973 .Mites of The Genus Cryptognathus from Australia , New Zealand and Nine land, Acarologia XV , I $53-75$.

8. Thor S. 1931. Acarina : Bdellidae, Nicoletiellidae Cryptognathidae - Das Tierreich Lief , $56-1-87$.

9. Womersley H. 1935. On Some Cryptognathid and Nicoletiellid Acarina from Australia and Bew Zealand - Anm .Mag . Nat .Hist m Ser 10,16 (19) . 151 154 . 


\section{وصف نوعين اكاروسيين جليدين من جنس Cryptognathus}

\section{(Acari:: Cryptognathidae)}

مجدي محمد حسين فوزي ، عابدين محمود خليل ، عصام محمد عبد السلام ياسين

$$
\text { معه بحوث وقاية النباتات - مركز البحوث الزراعية - الدقي - جيزة - مصر }
$$

L و Cryptognathus

تم تسجيل نوعين جديدين من الاكاروسات التابعة لجنس

Cryptognathus (Favognathus), Cryptognathus (Favognathus) rosetta sp.n.

aegyptiaca sp.n.

الكنتالوب و الذرة فى مدينتي رشيد (محافظة البحيرة) ودمياط (محافظة دمياط) على الترتيب. وتن

$$
\text { وصف النوعين مورفولوجيا ورسمهما. }
$$

